\section{Ensino superior e magistério da Igreja. A meta da verdade e o método do diálogo*}

\author{
João Décio Passos**
}

RECIBIDO: 18-10-16. APROBADO: 27-07-17

Resumo: O presente estudo expóe um panorama sobre a questão do ensino superior no magistério da Igreja Católica. Estrutura-se em dois tópicos que focam, respectivamente, as raízes históricas do ensino superior, no âmbito do processo de institucionalizaçáo do cristianismo e os textos do magistério dedicados ao assunto. Afirma que a tradição escolástica e o Concilio Vaticano II constituem dois epicentros em torno dos quais gravita a questão, sendo esse último a referência fundamental para o diálogo entre a fé a razão no contexto da sociedade plural e tecnocientífica de nossos dias.

Palavras-chave: Ensino superior; magistério de Igreja; universidade; fé e ciência.
Higher Education and the Magisterium of the Church. The Goal of Truth and the Method of Dialogue

AвSTRACT: This study presents an overview on the issue of higher education in the magisterium of the Catholic Church. It structures itself on two topics that focus on the historical roots of higher education in the context of the process of institutionalization of Christianity and on texts of the magisterium devoted to the subject. It affirms that the scholastic tradition and Vatican II Council constitute two epicentres around which the issue gravitates, the latter being the fundamental reference for the dialogue between faith and reason in the context of the plural and techno-scientific society of our days.

KeYwords: Higher education; Magisterium; University; Faith and Science.

\section{PARA CITAR ESTE ARTÍ́CULO:}

Passos, João Décio "Ensino superior e magistério da Igreja. A meta da verdade e o método do diálogo". Theologica Xaveriana 185 (2018): 1-25. https://doi. org/10.11144/javeriana.tx68-185.esmi

*Artigo de reflexão.

** Doutor em Ciências Sociais. Livre docente em Teologia; professor Associado do Departamento de Ciência da Religião da PUC-SP e professor do Instituto São Paulo de Estudos Superiores. OrCid 00000003-4390-0423. Correio eletrônico: jdpassos@pucsp.br 


\section{Introdução}

O ensino superior nasceu dentro da Igreja, no coração da Igreja, diz a constituição $E x$ corde ecclesiae. Estamos evidentemente diante de uma longa temporalidade, marcada, necessariamente, por enorme diversidade de contextos e de conceitos. O desafio dessa reflexão é, sem dúvidas, encontrar um fio condutor desse longo desdobramento de práticas e de conceitos referentes à educação superior.

Nessa história encontramos, de fato, as universitates em seu estado germinal, fruto de uma nova época que brota das novas relaçóes econômicas, sociais, políticas e culturais que vão sendo ensaiadas na Europa como os primeiros passos da chamada Modernidade. Aí a ciência aristotélica vai sendo acolhida pelas novas instituições de ensino e dialeticamente reformata o pensamento e cria novos sistemas teóricos. A Igreja está no comando das universidades e discute com as novas ciências: condena, negocia e assimila as novas ideias advindas do filósofo pagáo.

O século XIII constitui uma época emblemática de confronto cultural e de assimilação de novos paradigmas teóricos e metodológicos pelo pensamento cristão, tanto pela filosofia quanto pela teologia. A universidade nasceu no centro de um debate tenso e de uma invenção do novo que entrará para a história do ocidente como uma de suas instituiçóes fundamentais. A Modernidade refez a universidade, no âmbito de suas dinâmicas inovadoras que rompiam com as instituiçóes medievais.

A luta por autonomia colocou a Igreja fora da esfera pública e, por conseguinte, distante do ensino superior, assumido desde entáo como coisa de responsabilidade do poder público. Entretanto, a Igreja leva adiante sua tradição de ensino superior e recria suas instituiçóes dentro do Estado moderno, mais uma vez assumindo a missão da investigação, em nome da fé e da razão e, desde então, assumindo a causa de um humanismo de fonte cristá.

O ensino superior, assim como outros níveis de ensino, esteve entre as frentes mantidas pela Igreja em seus processos de inserção na sociedade e no mundo das ciências, como um dos serviços prestados ao ser humano em seus diversos contextos e como uma tarefa de formação humana e cultural e de investigação da verdade. O diálogo entre a Igreja e a cultura nos mais diversos contextos históricos regeu-se pela convicção da distinção e, ao mesmo tempo, da complementaridade das verdades da fé e da razão, adquirindo dinâmicas originais que, em meio a inegáveis tensões, produziram sínteses e personalidades distintas para as mais diversas ciências.

Falar da relação entre magistério e ensino superior é reconhecer, antes de tudo, uma ambiguidade permanente que demonstra da parte da Igreja as posturas de controle e de incentivo à investigaçáo, de rejeição e de assimilação das novidades 
apresentadas pelas ciências, de apaziguamento e de explicitação das verdades; em suma, de temor e de amor à verdade. Em seguida, é preciso reconhecer uma evolução do pensamento educacional católico. A Igreja pensa a educação superior em estreita relação com o que pensa de si mesma e o que pensa da sociedade na qual se insere. Em outros termos, os modelos de ensino superior estáo relacionados aos modelos de Igreja predominantes em cada época.

Os textos do magistério referentes à educação estão enraizados na longa tradição cristã e se mostram como uma de suas dimensôes de atuação no mundo, segundo o mandato evangélico do serviço ao ser humano e o processo de educação da fé. Essa tradição arranca-se da experiência cristá original e vai sendo construída no processo dialético que caracterizou o encontro de cosmovisóes distintas que tecem afinidades: a cultura judaico-cristá que se estrutura a partir da circularidade entre fato-interpretação-escrita e o pensamento grego, construído na relação fato-conceituação.

Esses modos de compreender o mundo e o ser humano encontraram no cristianismo uma experiência integradora que possibilitou confrontos e sínteses. A relação simbiótica entre interpretação e explicação construirá, de fato, a tradição cristã com todas as suas expressóes teóricas e práticas, dentre as quais deve ser incluída a educação.

A presente reflexão será encaminhada em dois pontos principais. $\mathrm{O}$ primeiro examinará rapidamente a tradiçẫo na qual os textos do magistério referentes ao ensino superior se enraízam. O ensino superior é um resultado do próprio processo de institucionalização do cristianismo no decorrer dos séculos. O segundo ponto focará propriamente esses textos, buscando neles alguns significados para hoje.

A extensão e complexidade desses dois tópicos desafiam a construção de qualquer síntese ou análise detalhada. $\mathrm{O}$ que segue constitui, portanto, nada mais que pontuaçóes que visam ajudar a pensar a grande questáo que hoje debate-se com a sociedade tecnocrática, estruturada na produção-consumo e globalmente conectada. Nesse contexto desafiante, a reflexão quer afirmar também que o Concilio Vaticano II oferece referências fundamentais e, em certa medida, ainda novas para orientar a práxis do ensino superior católico. $\mathrm{O}$ ensino superior pode ser visto como lugar privilegiado do discernimento dos sinais dos tempos, quando a sociedade e a cultura atuais assumem novas formas de expressão e novos valores em ritmos velozes e em extensóes complexas.

\section{As raízes do ensino superior cristão-católico}

O cristianismo nasceu como experiência judaica (uma experiência messiânica) formulada em grego (na língua e posteriormente nos conceitos gregos) no contexto do Império Romano (como organização social distinta da sociedade imperial). Esse 
dado histórico tem seu lado teórico, na medida em que foi sendo formulado para poder preservar-se e ser transmitido às geraçôes e, ao mesmo tempo, pensar a si mesmo como experiência distinta do judaísmo e do pensamento grego, porém em relação crítica e criativa com as duas tradições. O processo de organização (institucionalização e racionalização da experiência carismática cristã in statu nascendi) se deu como encontro entre duas posturas distintas perante a realidade:

- A postura judaica que interpreta a história em um ciclo composto de duas dinâmicas mutuamente complementares. Uma feita na direção fatointerpretação-escrita e outra na direção escrita-interpretação-fato. O resultado é uma composição incessante de interpretaçôes da história por meio de textos que se expandem em cada época em um movimento de releitura dos fatos do passado e do presente. A cultura judaica transmite essa prática interpretativa por meio de seus lideres carismáticos (os profetas) de suas lideranças políticas e religiosas, de seus escribas e professores. A história é o lugar em que Deus fala e o texto é o testemunho dessa experiência que vem do passado e avança para o futuro.

- A postura grega que busca compreender o mundo interrogando sobre seu funcionamento, assim como o ser humano em sua natureza biológica e social. A dinâmica do pensamento grego ocorre na relação que distingue o ser humano das coisas e o coloca como capaz de questionar e responder. A relaçáo fatointerrogaçâo-explicação entende a verdade não como uma revelação que vem de fora da mente humana, mas como fruto de sua capacidade investigativa, sendo o ser humano portador de uma alma inteligente.

O contato tardio do judaísmo com o pensamento grego produziu os primeiros exercícios de confronto e síntese entre a intepretação da história a partir da fé na revelação de Deus e a compreensão da realidade a partir da capacidade natural da alma humana. Em termos metodológicos, a interpretação recebe o auxílio da razão investigativa, a narrativa vai sendo conceitualizada. Filon de Alexandria é o pai reconhecido dessa operação que irá afirmar-se dentro do cristianismo, senão como o próprio cristianismo ${ }^{1}$.

Os seguidores de Jesus, o Cristo, interpretaram suas experiências em chave hermenêutica judaica: Jesus de Nazaré morto e ressuscitado é o Cristo enviado de Deus conforme atestam as Escrituras, a comunidade de seguidores são os herdeiros da promessa de Deus a Israel. Com efeito, essa interpretação foi feita em grego e foi

${ }^{1}$ Calabi, História do pensamento judaico-helenistico, 39-84; idem, Fílon de Alexandria. 
aprofundando-se e expandindo-se nas regras dessa língua e também dessa cultura. A formulação do próprio Novo Testamento não esteve livre de conceitos gregos advindos, sobretudo, do estoicismo, mas para alguns especialistas também do platonismo ${ }^{2}$. E uma vez que os textos interpretativos da experiência cristã vão sendo concluídos e adotados como norma para a comunidade, a pergunta grega pelo sentido da interpretaçáo e, por conseguinte, dos fatos narrados emergirá inevitavelmente, mesmo que sem um consenso por parte das lideranças.

A experiência da fé foi sendo pensada segundo o método grego. A era patrística é o resultado de longa duraçấo desse encontro que usa os conceitos e os métodos da ciência grega para interpretar a fé e, por conseguinte, a fé pensada para interpretar a história ${ }^{3}$. Essa tradição que relacionou fé e razão foi sendo construída e transmitida primeiramente por líderes cristãos, muitos dos quais vinham de escolas filosóficas gregas, e mais tarde pelas próprias escolas cristâs.

Dentre essas, a escola de Alexandria destaca-se como a grande pioneira. O ensino prossegue pelas escolas monacais na longa idade média, reproduzindo dentro da vida enclausurada a tradição dos padres da Igreja, particularmente o pensamento agostiniano formulado a partir de conceitos platônicos. Nessa longa temporalidade foi germinada a semente da qual brotou no ensino superior católico e, vinte séculos mais tarde, os textos do magistério normatizando a questão. E é, evidentemente, a partir dessa base cultural que as instituiçôes ocidentais e o próprio ocidente são formados no decorrer dos séculos ${ }^{4}$.

\section{O ensino superior em seu nascedouro}

A origem do ensino superior, mesmo que sujeita a controversas conceituais, pode ser localizada concretamente no século XIII como fruto do amadurecimento surpreendente das escolas urbanas, implantadas, já havia uns dois séculos, como resposta às novas demandas da vida citadina e possibilitadas, sobretudo, pelo comércio que dava seus primeiros passos. O novo modo de vida colocava novas possibilidades de relacionamentos, assim como novas necessidades para os cidadáos poderem produzir, vender e comprar e, por conseguinte, comunicarem-se entre si.

As escolas eram uma oferta de novos domínios culturais capazes de habilitar a classe social emergente que rompia com os padrôes de vida rural: a produção agrícola e as relaçóes estabelecidas entre senhor e servo, a arte da guerra e a catequese oral.

\footnotetext{
${ }^{2} \mathrm{Cfr}$. Theissen, $A$ religião dos primeiros cristãos.

${ }^{3}$ Vilanova, Historia de la teología cristiana I, 136-139.

${ }^{4}$ Nemo, O que é o Ocidente? 17-82.
} 
Aprender os rudimentos da cultura no clássico conjunto das sete artes liberais se tornava mais que um luxo de uma elite dedicada exclusivamente ao estudo e à contemplação como nas velhas escolas monacais; era, então, um meio de entender, de relacionar e dominar o novo mundo que se despontava.

As universidades nasceram como desenvolvimento dessas escolas; constituíram, por um lado, como uma espécie de síntese de uma nova sociedade na qual figuravam as corporaçôes autônomas - universitates- como nova prática organizativa, a busca de uma cultura que permitisse um relacionamento mais amplo entre os sujeitos e a discussão das novas bases da relação entre os poderes temporal e espiritual e, por outro lado, como uma resposta institucional às novas ciências que chegavam à Europa pelas mãos dos árabes: novos conhecimentos de medicina e de matemática e, de modo particular, os textos desconhecidos do filósofo Aristóteles 5 .

A Igreja entrou, de fato, nas cidades e desde o seu centro implantou suas catedrais e suas escolas. Não se tratava unicamente de uma estratégia política deliberada, mas de uma postura de protagonismo cultural, cujo fundamento estava calcado em uma tradição milenar que entendia a relação entre a fé e a razão como necessária e legítima. Portanto, acolher as novas ciências não consistia propriamente uma novidade, mas alinhava-se, a uma longa tradição cultural/eclesial que já o fazia com grande maestria. Crer e conhecer eram duas dimensóes do ser humano; era uma síntese acabada do encontro entre a tradição grega e a tradição cristã e também um programa para as novas escolas.

O ensino superior foi, desse modo, a instituição que demarcou definitivamente a passagem da cultura rural para a cultura urbana. A Igreja participou dessa passagem por meio das novas ordens religiosas entáo instaladas nas cidades e, ainda que de modo ambíguo, legitimou a organização dessas instituiçóes autônomas de saber: universitates. O princípio da autonomia da razão foi gestado em sintonia circular com a prática da autonomia do estudo; portava um aspecto teórico e outro prático. A teoria vinha, sobretudo, de Aristóteles qua entendia o conhecimento como uma construçáo feita pelo intelecto a partir da experiência concreta, de onde se podia chegar à verdade das coisas por meio do pensamento correto metodologicamente regrado pela lógica.

Em outros termos, todos poderiam alcançar a verdade na medida em que se dedicassem à investigação da realidade. A prática da autonomia vinha do novo contexto histórico que desenhava as primeiras formas de poder local por meio das corporaçóes já citadas. A Igreja vê nessa experiência um risco para a fidelidade à tradição e à hierarquia, mas ao mesmo tempo, entende a importância do ensino como meio de buscar a verdade que se identifica em última instância com o próprio Deus.

${ }^{5}$ Cfr. De Ridder-Symoens, História da universidade europeia, Vol. I. 
Portanto, a teologia fornecia a base para a legitimidade do estudo, naquele momento de elevação e expansão. Ainda soava forte o princípio anselmiano fides quaerens intellectum. A fé deve buscar os meios de compreensão através da razão. A teologia avança, pois, no exercício dessa regra já usual e se aplica ao estudo primeiramente das artes liberais, agora instituídas em uma faculdade cada vez mais organizada no ensino da filosofia. Somente após essa etapa propedêutica é que os estudantes se encaminhavam para uma das outra faculdades, a saber, a de Medicina, a de Direito ou a de Teologia.

No caso do estudo da teologia, o aluno se dedicava a ele já munido, portanto, dos instrumentos filosóficos -lógicos e metodológicos- já aprendidos anteriormente. O método era o dialético; consistia no confronto da tradição da fé com os referenciais filosóficos. Não se tratava somente de uma leitura lógica da doutrina da fé, mas também de um exercício que revia o próprio modo de expor a doutrina e, em última instância, a própria formulação da mesma. Conclusão: a razão formatava a fé, na medida em que a formulava de modo novo.

Essa prática significava aos olhos das dirigências da Igreja um risco para a fé, tendo em vista muitas das ideias aristotélicas, tais como, o conceito de eternidade do mundo, da união substancial entre corpo e alma (alma como forma do corpo), da inseparabilidade da substância e do acidente ${ }^{6}$. A vigilância aumentava, assim como os conflitos internos à universidade. $\mathrm{O}$ resultado revela um paradoxo: uma fase dramática para a vida da universidade, pontilhada de condenaçóes e uma era de grandes gênios que recriam a tradição teológica formulando um novo paradigma.

Entretanto, as sucessivas condenaçoóes aplicadas às obras aristotélicas e por decorrência a Tomás de Aquino ${ }^{7}$, revelam um curioso recuo perante a força da verdade que ali estava em jogo e que, de fato, se impunha como prática na vida universitária. O medo do novo vai dando lugar à assimilaçáo e a assimilação se tornará em pouco tempo um sistema oficial adotado pela própria Igreja: o sistema escolástico. Evidentemente, o novo sistema não significou uma concessão geral ao pensamento aristotélico, mas uma negociação entre a tradição agostiniana e essas novas ideias e, evidentemente, um reconhecimento da grandeza das sínteses elaboradas pelos grandes

\footnotetext{
${ }^{6}$ Grant, História da filosofia natural: do mundo antigo ao século XIX, 309-352.
}

${ }^{7}$ Em 1215 (Proibição da Física e da Metafísica pelos estatutos parisienses elaborado por Roberto de Courson), 1231 (proibição da Ética e do De anima por Gregório IX), 1255 (Faculdade de Artes institui o estudo da Física e da Metafísica), 1260 (mestres franciscanos denunciam o aristotelismo radical da Faculdade de Artes), 1270 (condenações às teses aristotélicas averroístas por Etienne Tempier, bispo de Paris), 1276 (mestres da universidade de Paris são condenados pela Inquisição), 1277 (condenaçôes de 219 proposiçóes ligadas ao aristotelismo da Faculdade de Artes e abertura de processo contra Tomás de Aquino, já falecido três anos antes). (Verger, Cultura, ensino e sociedade no Ocidente nos séculos XII e XIII, 277-297). 
mestres. Primeiramente por Alberto Magno e, logo em seguida, por seu grande discípulo Tomás de Aquino.

De qualquer modo, a autonomia do pensamento triunfou sobre o controle, a criatividade sobre o pensamento imutável e a nova ciência sobre os velhos currículos escolares há muito consolidados na tradição platônico-agostiniana. As universitates refizeram o pensamento, os métodos de ensino e os currículos escolares. E, desde entấo, a razão ocupa um lugar de destaque no processo de busca da verdade, como caminho legítimo que pode por si mesmo conhecer as coisas pelas causas, ou seja, construir ciências das coisas.

A Igreja inaugura assim sua obra de ensino superior como patrona das instituiçôes a ele dedicadas; tem de encarar a prática da autonomia dessas novas corporaçóes de saber. Vigilante da nova ciência e, ao mesmo tempo, reconhecedora da evidência da verdade, assume como missão natural a nova estruturação do conhecimento. A lógica dessa relação é a dialética entre a conservação e a renovação, na qual prevalecem as regras da assimilação tardia do novo, da incorporação do novo que preserva o antigo e da sedução pela descoberta da verdade.

\section{O ensino superior no coração da Igreja}

A bela afirmação de João Paulo II de que a universidade nasceu ex corde ecclesiae expressa não somente um fato histórico relativo aos sujeitos responsáveis por aquelas instituiçôes de ensino, mas também o apreço da Igreja por elas. O tópico anterior já expôs sucintamente o primeiro aspecto. Com relação ao apreço da Igreja, vale ainda indicar alguns pontos fundamentais. $\mathrm{O}$ amor ao saber era, de fato, uma herança antiga que a Igreja carregara e transmitira como tesouro oriundo do pensamento grego e da própria tradição judaico-cristã. Na expressão de Jaeger, a Igreja constituíra uma "paideia cristâ", na continuidade da clássica "paideia grega".

O encontro do logos grego com a sabedoria judaico-cristã construiu uma cosmovisão que agregou a capacidade humana de pensar e descobrir a verdade com a fé na verdade revelada por Deus. A busca da verdade constituía, assim, um exercício da criatura capaz de pensar e de chegar a Deus por essa via. Dizia Ambrósio e repetia Tomás de Aquino que a "verdade, venha de onde vier é do Espirito Santo" ". Agostinho formulou a regra fundamental "crer para compreender e compreender para crer" que vai acompanhar a história da Igreja como síntese das posturas humanas perante a realidade, quando o conhecimento das coisas reveladas por meio da fé se completa com o conhecimento das coisas por meio da razão.

\footnotetext{
${ }^{8}$ Cfr. Jaeger, Cristianismo primitivo y paideia griega.

${ }^{9}$ De Aquino, Suma teológica I-II, Q 109, art. 1.
} 
O cristianismo foi construído no decorrer dos séculos a partir dessa convicção e entendeu, portanto, o ato de ensinar-aprender como uma missão inerente à fé. A verdade vem de Deus e o seu conhecimento faz o homem feliz, entendia Santo Agostinho. A universidade nasceu, portanto, como fruto amadurecido de uma longa histórica de compreensão do ser humano, de sua natureza e destino, como criatura digna e decaída para a qual se orientava a ação educativa da Igreja. Do coração da Igreja, ou seja, de sua natureza e missão, o ensino foi sendo construído nos diversos contextos. Primeiramente com a referência antropológica agostiniana que entende a educação como um dos meios de realização do ser humana na sua escalada espiritual para Deus.

O século XIII, como já foi visto, introduz novas concepçôes na práxis pedagógica católica. O ser humano, embora continue sendo interpretado na referência agostiniana, é entendido como investido de autonomia. A educação da razão adquire nessa matriz um papel especial e é acolhida como um legítimo exercício de busca da verdade. A compreensáo do mundo com suas leis próprias, assim como da inteligência humana capaz de conhecer abre uma nova etapa histórica para a teologia e o pensamento de um modo geral. Deus á a fonte e a razão de todo conhecimento, sendo ele a própria verdade da qual decorrem todas as outras. O ser humano capaz de conhecer o mundo e a si mesmo pode errar, porém permanece autônomo nesse processo incessante de busca da verdade, cuja origem e fim coincidem com o próprio Deus.

O ensino superior moderno, filho direto do século XIII, foi gradativamente incorporando as ciências, tendo como ponto de partida a filosofia da natureza oferecida por Aristóteles. Mas foi somente no âmbito do Estado moderno que, de fato, se configurou uma nova universidade dedicada às ciências e às tecnologias. O velho humanismo medieval, marcadamente espiritual, cede lugar a um humanismo desconectado de bases teológicas. O ser humano entendido como um fim em si mesmo (Kant) e como capaz de conhecer sem necessitar da fé (das doutrinas reveladas) torna-se o sujeito e, ao mesmo tempo, a razão da educaçáo. O ensino superior adquire fins cada vez mais políticos no sentido da formação de cidadãos para viverem em uma sociedade plural e tolerante e de contribuir profissionalmente com a sua construçãa ${ }^{10}$.

Nesse contexto de um novo humanismo e de uma nova universidade, o ensino superior católico manteve-se reticente e acuado, reproduzindo-se sobre si mesmo a partir dos parâmetros da velha escolástica e do humanismo cristão. As autonomias modernas representavam um perigo. A separação entre as verdades da fé e da razão foi

\footnotetext{
${ }^{10}$ De Ridder-Symones, Uma história da universidade na Europa II, 511-538 (cfr. Porter, "A revolução científica e as universidades").
} 
condenada como perversa para o ser humano e para a sociedade (Vaticano I). Foram necessários alguns séculos para que a Igreja se voltasse para as autonomias modernas e se esforçasse para com elas dialogar. O papa Leão XIII iniciou um diálogo oficial em duas direções que, no fundo, possuem pontos em comum.

A primeira se refere à inserção dos cristãos no mundo moderno como força social e política em nome da fé, ou seja, de uma antropologia da dignidade intocável do ser humano (Rerum novarum, 1891). A segunda se refere à importância de voltar às fontes da escolástica consolidada havia séculos como pensamento oficial e como sistema fechado, distante das coisas novas modernas (Aeterni patris, 1879).

Com essas duas encíclicas são lançadas as bases de um humanismo que acolhe os desafios modernos e resgata as fontes clássicas tomasianas. As liberdades modernas e a tradição cristã entram em rota de confluência, após décadas de colisão. A partir de então a educação católica falará em formação do ser humano, em função social do ensino e em construção da solidariedade humana. Bem mais perto de nós o conceito de humanismo integral (J. Maritain) resume uma nova postura da Igreja que acolhe a ideia de que o ser humano é um valor em si e que a Igreja se apresenta como promotora e educadora desse valor.

O Concílio Vaticano II será o ponto de chegada dessa visão. O ser humano independente da raça, idade, sexo e religião é digno por natureza e deve ser defendido em seus direitos pela Igreja (Gaudium et spes). As liberdades modernas constituem um valor a ser respeitado e promovido (Dignitatis humanae). As ciências gozam de legítima autonomia como busca da verdade e como meio de realização da vida humana integral e como realização do desígnio de Deus (Gaudium et spes). A educação é um direito decorrente da dignidade humana e um processo essencial para o desenvolvimento das naçóes e do próprio ser humano (Gravissimum educationis).

$\mathrm{O}$ ensino superior permaneceu no coração da Igreja que, desde então, pulsa no ritmo do coração humano, marcado por todas as ansiedades e ambiguidades. Para os discípulos de Cristo "não se encontra nada de verdadeiramente humano que não lhes ressoe no coração" (Gaudium et spes 1). O ensino superior moderno se encaixa doutrinalmente nesse ponto de encontro entre o ser humano e o Evangelho, concretamente, entre a ciência e a fé, entre a autonomia da história e o desígnio de Deus, entre os métodos próprios das ciências e os valores inerentes à fé. Nas palavras de João Paulo II, visa unificar existencialmente duas ordens distintas, mas não antitéticas; "a investigação da verdade e a certeza de conhecer, já, a fonte da verdade" (Ex corde ecclesiae 1). 


\section{Os textos do magistério sobre o ensino superior}

Os textos do magistério que orientam direta ou indiretamente o ensino superior compóem um conjunto enraizado nessa tradição examinada na parte anterior. Nessa longa duração e nesse conjunto amplo eles se diversificam nos estilos e nas próprias orientaçóes. Uma exposição completa de todo esse conjunto se torna evidentemente impossível de ser feita nessa reflexão. Também não seria o caso de resenhá-los um a um em suas particularidades. Essas declarações acompanham a autocompreensão da Igreja sobre si mesma e sua missão no mundo e, por conseguinte, a sua compreensáo de mundo.

De qualquer modo, o ensino superior se torna objeto de reflexóes e deliberações do magistério em um contexto de luta com a razáo autônoma, a começar com as ciências aristotélicas. Todos eles representam um esforço reiterado de colocar as verdades da fé em confronto e em diálogo com as ciências que avançam para além dos regimes teóricos adotados pela Igreja como sua "ciência normal" (T. Kuhn). Esses regimes estruturados e adotados pela Igreja se consolidam como oficiais e também como fontes intimamente ligadas com a doutrina instituída, como deposito conceitual que serve à formulação da fé. Eis a razão de suas longas duraçóes e da reticência da Igreja em trocar de paradigma, quando provocada pelas novas ciências.

Foi o caso da primeira elaboração ao adotar o pensamento grego, particularmente os conceitos platônicos, da segunda ao adotar Aristóteles e as demais ao adotar elementos do pensamento moderno e contemporâneo. No primeiro momento formouse o agostinianismo, o pai de todos, no segundo a escolástica, o mais arquitetado, e no terceiro, após séculos, o Concílio Vaticano II, o mais sincrético e aberto. Ainda que permaneça a lógica da tradição - da transmissão de um depósito que renova preservando e que se preserva renovando- houve trocas necessárias ou inevitáveis. $\mathrm{O}$ platonismo optou por conceitos idealistas que romperam com a hermenêutica histórica de raiz judaica, a escolástica rompeu com a hegemonia do idealismo platônico em troca do realismo aristotélico e o Vaticano II rompeu com a hegemonia escolástica ao adotar uma racionalidade voltada para a história, por intermédio das novas teologias que vinham sendo elaboradas no decorrer do século XX.

\section{Os documentos do magistério}

$\mathrm{Na}$ verdade, não são muitos os documentos do magistério que se ocupam do ensino superior no seu sentido estrito. Como já foi exposto, a questão esteve no coração da tradição e de outros textos normativos do magistério, ora como questáo de fundo, ora como um tópico específico. Os textos referentes ao ensino superior se tornam 
mais frequentes precisamente nos tempos modernos, quando a prática de elaboração de textos por parte do magistério papal (assim como de documentos elaborados pela Cúria Romana) se torna cada vez mais regular e, após o Concílio Vaticano II, quando a elaboração de textos dos magistérios episcopais locais se torna possível e necessária como esforço de recepção das orientaçôes conciliares em cada realidade. Nos tempos pré-modernos, estando o ensino sob a custódia da Igreja, inseria-se em uma moldura teológica e em uma gestão política que dispensava justificativas sobre suas finalidades, enquanto nos tempos modernos exigirá a exposição mais detalhada de suas especificidades no âmbito da sociedade e do Estado laico.

$\mathrm{Na}$ sequência das encíclicas supracitadas de Leão XIII, os posicionamentos do magistério sobre educação têm no centro duas questôes interligadas entre si: a afirmação do direito à educação religiosa por parte das famílias e da Igreja, como decorrência da liberdade religiosa, e o reconhecimento do direito e do dever do Estado em promover a educação cívica do cidadão. A educação situa-se nessa interface política entre o Estado e a Igreja como uma questão fundamental para ambas as instituiçóes.

É nesse contexto e com esse intuito que Pio XI escreve a encíclica Divini illius magistri em 31 de dezembro de 1929. A "questão romana" recém-resolvida nos Acordos de Latrão entre o Pontífice e Mussolini e as açóes subsequentes do mesmo político em plataforma fascista no campo da educação compóem o pano de fundo imediato do conteúdo da encíclica. A crescente centralização da educação da juventude por parte da ideologia do partido fascista e as perseguiçôes à Ação Católica, pupila declarada do papa, haviam criado, de fato, problemas diplomáticos entre a Igreja e o regime e provocado pronunciamentos do sumo Pontífice e do Senado italiano ${ }^{11}$.

A encíclica de Pio XI foi a primeira no gênero e constitui um marco nos tempos modernos, emblema nítido das soluçóes em curso que delineavam as funçôes da Igreja e as funçôes do Estado dentro da sociedade laica. Em suma, o papa vai afirmar uma concepção de educação que consiste em educar o ser humano em sua totalidade, delinear as responsabilidades pela educação à família, à Igreja e ao Estado, condenar o laicismo escolar e conclamar os leigos à tarefa educativa. Há, naturalmente, um fundamento último da educação de natureza teológica que significa alcançar a salvação dentro do paradigma agostiniano acima referido ${ }^{12}$.

Nas ações do mesmo pontífice é ainda digna de nota a promulgação de uma constituição apostólica sobre as universidades católicas e faculdades eclesiásticas no ano de 1931: Deus scientiarum dominus. Essa breve constituição recorda a missão

\footnotetext{
${ }^{11}$ Foulquié (org.), A Igreja e a educação, 105-141.

${ }^{12}$ Pio XI, Encíclica Divini illius magistri.
} 
evangélica e açóes históricas da Igreja em prol da educação e das ciências, referindose explicitamente às ciências profanas. Deus sendo o autor das ciências delegou à Igreja a missão de ensinar, donde decorre seu compromisso de "progenitora e de protetora da ciência", atividade que se efetiva pelas vias da fé e da razão. Posta essa base teológica, o documento passa a descrever as açóes históricas da Igreja em suas instituiçóes educativas, particularmente as universidades. Conclui com enunciados práticos sobre o fomento e organizaçáo das escolas eclesiásticas, responsáveis pelo ensino das chamadas ciências sagradas ${ }^{13}$.

Vale observar que após os documentos de Pio XI, salvas as pontuais declaraçôes de Pio XII, e a declaração Gravissimum educationis do Concílio Vaticano II, somente em 15 de agosto de 1990 é que um novo documento específico e de fôlego sobre o ensino superior foi produzido pelo magistério eclesiástico ${ }^{14}$ : a constituição apostólica Ex corde ecclesiae. Antes dessa, em 1979 o mesmo papa publicara outra constituição relacionada à questão, porém dedicada especificamente às faculdades eclesiásticas: Sapientia christiana. A declaração conciliar sobre a educação situa-se coerentemente dentro do espírito e dos rumos gerais do Concílio, basicamente no diálogo da Igreja com os tempos modernos. No que se refere ao ensino superior, a declaração reconhece a autonomia de investigação nas especificidades de cada disciplina e afirma o objetivo de que essas instituiçóes formem sujeitos verdadeiramente preparados para atuarem na sociedade e testemunhar a fé no mundo. Afirma ainda o princípio da qualidade como distintivo das universidades católicas e sua função social em favorecer o acesso de estudantes pobres aos seus cursos ${ }^{15}$.

Com maior fôlego que a constituição de Pio XI, a de João Paulo II está estruturada em duas partes, uma primeira sobre os fundamentos e uma segunda sobre as normas para a organização das universidades católicas, segundo os parâmetros do Direito Canônico. O documento reflete, naturalmente, o contexto em que é escrita, ou seja, as orientaçôes do Concílio Vaticano II, o novo Código de Direito Canônico promulgado em 1983, os avanços das ciências e o crescimento do número de universidades católicas em todo o mundo a partir do século XX. As reflexôes oferecem uma compreensão sobre a identidade e a missão das universidades católicas nos tempos atuais, tarefa que exige articular, sem prejuízos, inspiração cristã e atividades científicas. Reconhece, mais uma vez, a autonomia universitária na investigação e no ensino, a importância da universidade para a Igreja e a sociedade e a necessidade de se pautar

\footnotetext{
${ }^{13}$ Idem, "Constituição apostólica Deus scientiarum dominus".

${ }^{14}$ Stein, A educação nos documentos da Igreja Católica Apostólica Romana, 46-50.

${ }^{15}$ Concílio Vaticano II, "Declaração Gravissimum educationis sobre a educação cristã” 10.
} 
as práticas acadêmicas a partir dos princípios cristãos. No tocante a missão, fala em quatro características da universidade católica:

- Inspiração cristá dos indivíduos e da comunidade universitária.

- Reflexão permanente sobre os tesouros do conhecimento humano a luz da fé católica.

- $\quad$ Fidelidade à mensagem cristã.

- Empenho institucional no serviço à família humana.

No que se refere à missão da universidade, o papa afirma como fundamental a busca contínua da verdade e a conservação e comunicação do saber, donde decorre o compromisso de contribuir com o desenvolvimento humano, com o diálogo entre as culturas e com a consciência ecológica. Fala ainda em três açôes a serem desenvolvidas pela universidade: a pastoral universitária, como açáo integradora da vida e da fé, o diálogo cultural dentro da universidade e a evangelização que deve contar com a universidade no momento de dialogar com os diversos aspectos da sociedade atual ${ }^{16}$.

Após o Concílio, na América Latina, o Documento de Buga, como ficou conhecido, compôs um conjunto de orientaçóes fecundas para as universidades latinoamericanas e ainda faz sentir seus ecos em muitas delas, sobretudo no que se referem as sua identidade e missão social. O documento elaborado pelo Celam apresenta uma visão cristã de cultura, propondo o diálogo como caminho para as relaçóes entre cristianismo e cultura. Nesse diálogo está incluída, necessariamente, a articulação entre fé e ciência como meio de chegar á verdade.

O documento afirma também que a missão da Igreja é servir o mundo e indica a missão das universidades no desenvolvimento das comunidades latino-americanas. Pode-se dizer que esse documento histórico significou uma recepção madura do Vaticano II, recolhendo o ensino conciliar de um modo geral, sobretudo a sua eclesiologia do serviço e sua teologia do mundo, postura que até mesmo por razóes cronológicas a declaraçáo conciliar sobre a educação não pôde adotar, uma vez que foi aprovada antes das constituições Lumen gentium e Gaudium et spes ${ }^{17}$. A universidade confessional situase, segundo Buga precisamente nessa confluência de uma Igreja que acolhe os apelos da realidade e se dispóe a servir a sociedade por meio da educação. Esse documento registra, desse modo, o deslocamento de uma abordagem primordialmente política da educação (direitos dos cidadãos cristãos dentro do Estado laico) para uma abordagem social: como tarefa inerente à missão da Igreja em cada contexto em que se insere e como meio de promoção da libertação integral do ser humano ${ }^{18}$.

\footnotetext{
${ }^{16}$ João Paulo II, Constituição apostólica Ex corde ecclesiae, parte I.

${ }^{17}$ A declaração Gravissimum educationis foi aprovada em 13 e 14 de outubro de 1965.

${ }^{18}$ Celam, Os cristãos na universidade 11-22.
} 
É importante ressaltar que as orientaçóes oficiais da Igreja situam-se, naturalmente, no âmbito da proposição de fundamentos e de princípios norteadores da práxis educacional. Elas não tocam nos grandes problemas da articulação entre inspiração cristã e ciência, no momento concreto da pesquisa e nem nos desafios organizacionais das universidades, quando de sua sustentabilidade e estruturação financeira e burocrática. Podemos dizer que são orientações que reproduzem a compreensão clássica de educação e de universidade, acumuladas pela Igreja ao longo de sua história, no esforço de manter sua identidade nos tempos atuais. Permanece, contudo, uma distância visível entre as orientaçóes e as práticas que se concretizam, de fato, na distância entre o formalmente instituído e as práticas acadêmicas nas universidades.

Nesse sentido, vale ressaltar mais uma vez que a afirmaçáo da identidade e missão das universidades católicas é uma tarefa permanente de construção a partir das necessidades reais de cada época e contexto e dos referidos princípios emanados da Igreja. Não encontramos, nesse sentido, universidades reais nas orientaçoóes do magistério, bem como muitas dessas orientaçôes não são praticadas integralmente nas universidades concretas. O que se impóe é, certamente, um círculo virtuoso construtivo entre princípios e realidade, o que se faz em projetos concretos desenvolvidos nas universidades, garantindo, por um lado, unidade e coerência no âmbito das inspiraçóes comuns e, por outro, diversidades de modelos concretos inseridos em cada realidade.

Mas há que ressaltar também que as orientaçôes do magistério a respeito do ensino superior estão sempre situadas historicamente, como ocorre com outras questốes. A própria sucessão de documentos emitidos revela a necessidade de atualização das orientaçóes da Igreja, na medida em que a história avança com seus problemas e o pensamento humano com seus novos modos de explicar as coisas e interpretar o dado humano ${ }^{19}$.

Nesse sentido, é possível perceber evoluçóes nas orientaçóes do magistério nos documentos mencionados. Se, até meados do século passado, a problemática girava em torno do direito da educaçáo católica no âmbito do Estado laico e da afirmaçáo da legitimidade uma racionalidade teológica, hoje a questáo principal diz respeito, sobretudo, à busca de uma relação interdisciplinar no âmbito das praticas acadêmicas, de forma que permita às diversas ciências avançarem para patamares mais amplos e profundos do conhecimento e possam contribuir com a vida humana no conjunto da vida planetária ${ }^{20}$.

Contudo, persistirâo sempre defasagens entre as orientaçóes do magistério e os avanços vertiginosos das ciências. Essas chegam antes daquelas e assumem formas

\footnotetext{
${ }^{19}$ Tarnas, A epopeia do pensamento ocidental, 245ss.

${ }^{20}$ Japiassu, Ciência e destino humano, 247-278.
} 
curriculares e institucionais que, muitas vezes, desconfortam as orientaçóes da Igreja. Porém, como reza a tradição clássica, a verdade prevalecerá sempre e será a meta permanente de toda investigação. Por conseguinte o diálogo constituirá cada vez mais o método de relacionamento ente magistério e ensino superior no contexto do avanço das ciências, assim como dos limites cada vez mais visíveis de suas aplicaçôes ${ }^{21}$.

$\mathrm{O}$ conjunto dos documentos revela também uma evolução no pensamento do magistério sobre o ensino superior, quando se verifica em cada um deles o seu foco central, ou os lugares a partir de onde falam. O lugar político prevalece nitidamente como preocupação central até o Vaticano II: o direito das famílias de escolher o tipo de educação, o direito da Igreja em oferecer o ensino e o dever do Estado de garantir esse direito. No epicentro do grande Concilio os lugares social (a função do ensino superior no desenvolvimento dos povos) e epistemológico (o diálogo com as ciências) adquirem maior relevância. Já no pós concilio aparecem com mais força os lugares cultural e religioso (o diálogo com as diversidades presentes na sociedade e dentro da própria universidade). O último documento produzido pela Congregação para a Educação Católica (18 de outubro de 2013) toca diretamente na questão do diálogo com a diversidade religiosa ${ }^{22}$.

Por fim, é forçoso observar que a questão do ensino superior, não obstante sua longa tradição dentro da Igreja -ou talvez precisamente por essa razáo-, não constitui um objeto revisitado reiteradamente pelo magistério, como se pode verificar, por exemplo, em relação aos documentos sociais que, em pouco mais de cem anos, construíram uma sólida tradição numa cadeia de conceitos e de análises que avançam e se mostram bem sintonizadas com as conjunturas históricas.

Esses poucos documentos parecem carecer de reflexôes capazes de protagonizar parâmetros para uma educaçáo superior convincente no diálogo crítico com as ciências e atirada na transformaçáo social. O ensino superior seria uma questáo já resolvida, tendo em vista sua longa tradição no coração da Igreja e a existência de um número expressivo de instituições católicas? Ou, na postura de mestra a Igreja já teria dito o suficiente? $\mathrm{Ou}$, ao contrário, tendo em vista o avanço das ciências, o cuidado seria a postura mais prudente? Ou, por fim, o respeito à autonomia dessas instituiçóes, o que a Igreja declara como valor e regra, dispensaria orientaçóes frequentes e muito diretas?

O fato é que nesses documentos tem prevalecido a modéstia sobre a ousadia. $\mathrm{O}$ fato é que a Igreja ainda busca um lugar no mundo moderno que avança na

\footnotetext{
${ }^{21}$ Leers, Moral cristã e autoridade do magistério eclesiástico, 79-106.

${ }^{22}$ Congregación para la Educación Católica, "Educar para o diálogo intercultural na escola católica. Vivir juntos una civilización de amor".
} 
investigação científica, quase sempre à frente da doutrina católica e desfaz muitos de seus paradigmas e instituições.

\section{Dois epicentros fundamentais dos textos do magistério}

Como já foi analisado, o ensino superior católico constitui a expressão institucional de uma longa tradição filosófica, teológica e pedagógica elaborada e transmitida pela Igreja; nasce como dimensão da própria missão da Igreja na sociedade e, por conseguinte, carrega as compreensóes elaboradas pela Igreja sobre as ciências, sobre si mesma e sobre o mundo. Os documentos do magistério a respeito do assunto têm seu lugar no contexto da modernidade, quando se intensifica o estilo encíclica ${ }^{23}$ e se coloca como problema a legitimidade da educação católica dentro dos estados modernos.

Portanto, coloca-se de um lado a Igreja com suas tradiçóes e com a centralidade do magistério papal e, de outro, o mundo moderno com suas instituiçóes. A Igreja vai retomando sua inserção dentro do mundo moderno e afirmando seu modo tradicional de compreender a relação entre a razão e fé. Essa explicitação não fora necessária na baixa idade média e nos primeiros momentos da Modernidade, quando ela detinha toda legitimidade junto ao ensino superior. Por outro lado, quando da instauração dos estados modernos havia sido expulsa das universidades que passam para as máos do poder público e permanecera reclusa às suas escolas de natureza eclesiástica, restritas ao ensino de teologia e filosofia, destinado unicamente à formaçáo do clero.

Os documentos referentes ao ensino superior significam a fundamentação de uma retomada da Igreja do ensino superior no âmbito dos estados modernos, ao menos de vários estados, como no caso emblemático do Brasil (possui dezenas de universidades confessionais e, desde a década de quarenta, as universidades pontifícias. Conta hoje com sete dessas universidades). De fato, quando a Igreja detinha o poder direto sobre o ensino superior não necessitava agir a não ser por vias canônicas em relações às suas instituiçôes, como ainda pode ocorrer em relação a algumas escolas eclesiásticas. É no âmbito de um ensino superior moderno -constituído pelas regras epistemológicas e políticas modernas- que as orientaçóes do magistério se tornam mais fundamentais no sentido de garantirem uma identidade católica do exercício universitário, seja no estabelecimento dos parâmetros gerais da investigação, seja na garantia de uma função humana, pedagógica e social do ensino superior segundo a tradição cristã-católica.

Por conseguinte, nesse contexto de relação direta com a educação pública moderna de responsabilidade do Estado, pode-se dizer que a Igreja pensa o ensino superior a partir de dois epicentros principais. Esses epicentros se sucedem historicamente como

${ }^{23}$ O’Malley, O que aconteceu no Vaticano II, 67-69. 
compreensão fundamental da relação fé e razão e da própria relação da Igreja com a sociedade, porém se completam no momento das reflexōes mais recentes. Trata-se dos epicentros da Escolástica e do Vaticano II $^{24}$. O primeiro construído, ou concluído, na baixa idade média, funda-se no princípio da relação entre as verdades da fé da razão, verdades distintas, porém complementares a partir das quais se estruturam os currículos dos cursos superiores das áreas de conhecimento. A metafisica garante com seu edifício a unidade última dos saberes e fornece à verdade da fé uma moldura conceitual segura que lhe permite transitar entre as ciências como uma verdade integradora. A partir desse epicentro epistemológico que aos poucos recebe influxos renovadores com a volta às fontes tomásica, os documentos do magistério fundamentam suas orientaçóes sobre o ensino superior.

O resgate de Tomás de Aquino desde o século XIX permitiu construir pontes com o mundo moderno com suas instituiçôes autônomas, dentre às quais a universidade e as próprias ciências. O princípio da não contradição entre as verdades de fé e de razão, aliado a uma visão social que insiste na função social dos bens materiais e culturais dava os rumos e os caminhos de uma retomada do ensino superior por parte das igrejas locais. Os documentos promulgados até o Vaticano II gravitam em torno dessa tradição e reivindica o direito da Igreja de organizar suas instituições de ensino dentro do Estado moderno. A Igreja tem o dever de oferecer educação para os seus fieis que, por sua vez, têm o direito de obtê-los, bem como de contribuir com o desenvolvimento dos povos em seus diversos contextos por meio da educaçáo.

O epicentro do Vaticano II, embora cronologicamente posterior, não exclui, evidentemente a tradição escolástica com suas molduras metafisicas, com seus princípios ontoteológicos e com suas metodologias dedutivas. Ao contrário, ainda utiliza essas referências como um porto seguro de suas reflexôes. A encíclica Fides et ratio constitui exemplo emblemático dessa opção teórico-metodológica. Porém, em coerência com a postura dialogal do Concílio novos elementos merecem ser destacados e que, em certa medida, ainda não foram plenamente traduzidos nos tempos atuais:

1. O reconhecimento explícito da autonomia das diversas ciências modernas com seus distintos métodos e objetos.

\footnotetext{
${ }^{24}$ No caso do Vaticano II, trata-se do conjunto das orientaçôes conciliares, de modo particular aquelas presentes na constituição Gaudium et spes que fornece a orientação mais completa sobre as relações da Igreja com o mundo e, ao mesmo tempo, uma teologia do ser humano, do mundo e da ciência. A declaraçâo Gravissimum educationis, embora verse diretamente sobre a questão da educação católica, ainda permanece aquém de uma antropologia e de uma epistemologia que possibilitem o diálogo efetivo da Igreja com as dinâmicas concretas do ensino superior no âmbito da sociedade moderna.
} 
2. A afirmação de uma teologia do conhecimento que insere os avanços das ciências e das tecnologias no plano misterioso de Deus para a humanidade, sendo o ser humano criado à sua imagem e semelhança.

3. A insistência no diálogo entre as ciências e a teologia como caminho necessário da ser trilhado no ensino superior.

4. A afirmaçấo de um humanismo universal do qual participam as diversas tradiçóes e a tradição cristã.

5. A convicção da função humanizadora e profissional das universidades católicas na formação de cidadãos responsáveis pelo destino de suas comunidades.

6. Ainda, a afirmação da função social de ensino superior como meios de superação da pobreza.

Portanto, sob o amparo da clássica tradição que distingue e relaciona fé e razão, do respeito à autonomia das ciências e o diálogo permanente na busca da verdade o ensino superior está fundamentado nos documentos do magistério. Pode-se afirmar que em seu conjunto os textos promovem alguns encontros, ainda que no plano teórico:

1. Entre o humanismo moderno e o humanismo cristão, ao afirmar o ser humano como um valor em si mesmo, independente da condiçấo que ocupe.

2. Entre a tradiçáo clássica e as ciências modernas, ao afirmar a legítima autonomia dessas.

3. Entre a missão social e cultural da Igreja com as funçôes do Estado em relação á educação.

4. Entre educação e evangelização, entendendo a educaçâao como um meio de promoção da dignidade humana.

Esses encontros se fazem, por conseguinte, por meio do diálogo que se mostra:

1. Como processo de construção que envolve não somente crentes, mas os sujeitos de ciências de um modo geral.

2. Como busca conjunta da verdade e afirmação de uma finalidade ética da educação.

3. Como escuta da diversidade que compóe o mundo da investigação nas muitas ciências e métodos e pelos esforços de sujeitos igualmente diversos.

4. Como esforço permanente de tradução dos valores de fé em valores humanos a serem praticados e buscados no processo de formação intelectual e profissional.

5. Como projeto comum formulado pela comunidade universitária tendo em vista o mesmo objetivo de educar para a competência e a ética, para a convivência e a paz.

Esses dois epicentros estáo presentes no pensamento do magistério atual sobre o ensino superior. $\mathrm{O}$ primeiro oferece um arcabouço que permite incluir as ciências 
em um esquema que as conecte com a pergunta pela finalidade: $o$ que das coisas respondido juntamente com o para que. A finalidade ética se torna o princípio capaz de unificar as práticas cientificas em torno de algo assumido como valor para o ser humano e para a vida. O segundo, incorporando o primeiro, insiste na necessidade do diálogo com as áreas de conhecimento legitimamente autônomas e na função social do ensino. No primeiro, a Igreja afirma-se como portadora de uma tradição e com ela se propóe a ensinar. No segundo, sem negar sua postura de mestra, a Igreja se dispóe a aprender com as ciências e, a partir, delas buscar sínteses mais amplas e profundas que se coloquem a serviço da humanidade. No período pós-conciliar cada um dos epicentros se mostra mais ou menos visível, a depender do documento ou mesmo do assunto que é tratado. Mas, eles compóem quase sempre o pano de fundo das reflexôes e declarações da Igreja sobre o ensino superior.

Como desafio concreto de aplicação dessas orientações, prevalece a necessidade de a Igreja fazer a tradução permanente de suas orientaçóes às realidades presentes. A relação entre fé e razão tem nomes precisos em nossos dias: a relação entre as ciências (os resultados e os métodos) com a tradição da fé. E nome da verdade, o caminho legítimo só poderá ser o do diálogo, sendo que essa legitimidade se impóe em nome da epistemologia atual que visa superar os isolamentos das ciências e em nome da própria fé que, em nome de Deus, afirma a verdade como a razáo de ser de toda a investigação, mesmo em conjunturas de contradiçóes ou quando o magistério não tem uma resposta concluída sobre algum assunto:

A Igreja, guardiã do depósito da palavra de Deus do qual tira os princípios para a ordem religiosa e moral, ainda que não tenha respostas imediatas para todos os problemas, deseja unir a luz da revelação com a perícia de todos, para que se ilumine o caminho no qual a humanidade entrou recentemente. (Gaudium et spes, 33)

Contudo, a Igreja ainda busca seu lugar dentro da modernidade, apesar do Vaticano II ter lançado as orientaçóes fundamentais desse relacionamento crítico e construtivo. Os pronunciamentos do magistério supracitados carregam os limites e as potencialidades desse encontro em pleno curso e inconcluso. A Igreja sai do Concílio com uma nova postura perante o tempo e o espaço da cultura moderna: fazer permanentemente o discernimento dos sinais dos tempos (Gaudium et spes 4,11 e 44).

Essa orientação não foi levada às últimas consequências no momento de se pensar a relação da Igreja com as expressóes culturais modernas, sobretudo com aquelas que se distanciam da tradição doutrinal e que expóem questóes novas que fogem dos referencias hermenêuticos utilizados particularmente nas orientações morais. Mas, é precisamente no instante da formulação-reformulação doutrinal que o princípio do 
discernimento nem sempre se faz valer, quando o magistério recorre aos lugares comuns da fundamentação e da transmissáo da doutrina para comunicar suas orientaçóes. As questóes relacionadas à genética, à sexualidade e à vida familiar são, por certo, as mais exemplares desse distanciamento entre a fé as práticas culturais e científicas.

Vale recordar que o princípio lançado por João XXIII e seu discurso de abertura dos trabalhos conciliares ainda aguarda sua plena efetivação. A distinção feita pelo progenitor do grande Concílio entre a "substância" e a "formulação" da doutrina (Gaudium et spes 62; Nota 12 de pé de página) se mostrou eficaz nas reformulaçóes empreitadas pelos padres conciliares em muitos pontos da doutrina católica durante os trabalhos nas assembleias daquele grande Sínodo e se mostra visível nos textos oficiais que foram promulgados.

Porém, o mesmo princípio não parece ter continuado operando com a mesma força durante o período de recepçáo conciliar, na medida em que o carisma do aggiornamento ia perdendo seu fôlego original. $\mathrm{O}$ mundo moderno mostrou, desde entáo, suas expressóes mais acabadas e radicalizadas, enquanto o magistério optava, muitas vezes, por uma postura de ensino que repetia a doutrina sem esforços de reformulá-la para melhor colocar a mensagem da fé em sintonia com as problemáticas modernas.

O papa Francisco tem retomado com ousadia esse princípio do discernimento mútuo entre a doutrina e a realidade, como se pode verificar em seus discursos e em seus ensinamentos oficiais (Evangelii gaudium 41). A práxis do magistério se faz no discernimento e não no ensinamento que repete de modo intacto a formulação do passado. Para isso, náo precisaria sequer produzir novas orientaçóes. A Igreja ensina de novo pelo fato da realidade se renovar e trazer novas interrogaçóes. E para a formulação-reformulaçáo da doutrina que ocorre nesse exercício conta não somente com a tradição já instituída, mas também com os conhecimentos que vão sendo elaborados em cada tempo e lugar pelas várias ciências, explica Francisco retomando o ensinamento de João Paulo II (Evangelii gaudium 40-41). Em suma, a Igreja ensina discernindo e não simplesmente repetindo sem prestar atenção à realidade concreta.

\section{Considerações finais}

A fé que busca ciência constitui o princípio que regeu as relaçóes de fundo da Igreja com o ensino superior desde as suas origens mais remotas e permanece ainda hoje como um princípio norteador da prática da Igreja no âmbito da cultura. A vocaçáo encarnatória da fé cristã a coloca dentro das mais diversas realidades e fá-la dialogar com as diferenças aí presentes, mesmo quando essas destoam do repertório instituído da fé. A fé encarna-se na história por meio das linguagens disponíveis para expressar 
a verdade do real e nessa dinâmica, renova-se permanentemente em seus modos de expressão.

Nesse sentido, seguindo a lógica de sua história passada, o cristianismo continua formulando a si mesmo em sintonia com os recursos teóricos, metodológicos e políticos disponíveis em cada contexto. O ensino superior é, certamente, o lugar privilegiado dessa auto formulação, tendo em vista a sua capacidade critica e criativa em propor formas de pensar a realidade de um modo geral. Pode-se dizer que sem o ensino superior o cristianismo náo seria o mesmo, ao menos em sua versão ocidental. E sequer é possível separar de modo concreto a experiência do carisma cristáo fora das mediaçôes racionais e racionalizadoras advindas do pensamento grego onde ele se expressou e tomou suas formas.

A história cristã nos ensina que é no presente que a fé é vivenciada como dom que vem do Ressuscitado e vai adquirindo suas formulaçóes; no tempo provisório o cristianismo busca permanentemente os modos mais adequados de se fazer entender e de se organizar. O magistério da Igreja participa dessa missáo na qualidade de voz oficial, de ministério que formula a verdade da fé em sintonia direta com cada tempo e espaço e de exercício de consciência crítica da tradição cristá que deve ser repassada em nome de seu carisma fundante. A fé institucionalizada pelo magistério é uma instância relacionada com outras dentro dos ministérios eclesiais; antes de tudo com aqueles que examinam e propóe novas formulaçôes para a fé: os teólogos. Esses por sua vez só podem exercer suas atividades em conexão direta com o mundo das ciências.

Nesse sentido, magistério e ensino superior estão diretamente relacionados como as duas pontas da expressão da verdade e como atividades que se interagem em torno dessa causa, mesmo quando disso não se têm consciência. As ciências abrem as clareiras, a teologia constrói a estrada e o magistério faz a pavimentaçáo. A estrada, porém deve ser mantida e refeita perante a erosão do tempo e as novas técnicas de aperfeiçoamento de sua engenharia geral.

No marco conciliar, o princípio do discernimento dos sinais dos tempos demarca a postura de diálogo da Igreja com as variadas realidades, como aquela que ensina aprendendo. $\mathrm{O}$ mesmo Espirito da verdade atua dentro e fora da Igreja, dentro e fora da tradição, dentro e fora da doutrina. A partir dessa convicção, o discernimento e o diálogo são adotados como regra nas relaçóes da Igreja com a cultura atual em mudança permanente, como ensina o Vaticano II:

...a Igreja precisa do auxílio, de modo particular, daqueles que, crentes e nãocrentes, vivendo no mundo, conhecem bem os vários sistemas e disciplinas e entendem a sua mentalidade profunda. Compete a todo povo de Deus, principalmente aos pastores e teólogos, com o auxílio do Espirito Santo, auscultar, discernir e interpretar as várias linguagens de nosso tempo, e julgá-las à luz 
da palavra divina, para que a verdade revelada possa ser percebida sempre mais profundamente, melhor entendida e proposta de modo mais adequado. (Gaudium et spes 44)

O ensino superior situa-se na fronteira da fé com a razão, da Igreja com a cultura, do magistério com as ciências. É a ponte que permite a construção dos trânsitos da fé para sociedade e vice versa, um modo excelente de encarnar a realidade da fé em práticas e linguagens que se legitimam por suas coerências e eficácias transformadoras do mundo e da sociedade, mediante as aplicaçôes tecnológicas.

Por essa razão, no interior do ensino superior a fé cristã pode tocar no coração da sociedade moderna, onde, por meio da pesquisa e da formação de profissionais, destinos sáo traçados para os projetos dos povos e, em certa medida, para a própria humanidade. O ensino superior confessional constitui, de fato, a ponta de lança da tradiçâo cristã transmitida então sob o teste da razão que exige renovação e coerência; constitui também o espaço do encontro mais natural entre a tradição da fé e o espírito humano que investiga, descobre e faz ciências compóe a arena da luta dos paradigmas que formulam as verdades e as devolvem à sociedade como meios de construção de diferentes metas.

Não se trata, portanto, de uma encarnação da fé em um corpo morto, mas, ao contrário, em um corpo que tem vida própria, que prepara o futuro e que forma personalidades. O ensino superior náo pode ser jamais espaço de poder eclesial, exercido em nome de uma verdade única e perene ou de um poder institucional que exibe à sociedade sua força e sua coerência. Ao contrário, é o lugar do diálogo e do serviço à humanidade que conduz por meio das ciências e das técnicas o seu próprio destino. O futuro da humanidade se mostra como meta que clama por horizontes de valores que contribuam com a construção do mesmo de modo sustentável para a espécie humana e para o conjunto da vida, conclama-nos hoje Francisco na encíclica Laudato si. Na sintonia com o presente e com o futuro o magistério da Igreja pode falar sempre de novo e:

- Afirmar o ser humano como valor comum para o qual confluem os valores do evangelho, das ciências e da formação profissional e, portanto, como tradução concreta da fé no Deus encarnado.

- Negar a homogeneização de pensamento em nome do diálogo permanente com a diversidade.

- Afirmar o valor da autonomia da investigação como valor em si mesmo e rejeitar toda forma de imposição da verdade.

- Adotar a busca permanente da verdade como espírito e método que conduz toda a açáo acadêmica dentro da universidade e negar as fixaçóes da mesma. 
- Encarar os conflitos entre a ciência e a fé como dinâmica inerente ao espirito e às instituiçóes humanas, rejeitando toda forma de conformismo, bem como toda forma de medo que impede o diálogo.

- Acolher as verdades - mesmo que neguem a fé- como possibilidade de aprendizagem para a própria fé e para a Igreja.

- Discernir as possibilidades de traduzir a mensagem da fé nos códigos das ciências de forma a torná-la mais clara e coerente para a cultura contemporânea.

- Orientar os modos concretos de traduzir a relação dinâmica entre fé e razão em modelos e práticas acadêmicas, assim como em modos de gestão institucional que aliam autonomia política e identidade confessional.

- Conclamar todas as ciências para a responsabilidade ética em relação à vida da humanidade em suas relações globalizadas.

- Buscar os meios de colaboração entre a ciência e a teologia, visando à construção de consensos capazes de instar projetos de vida mais fraternos e sustentáveis.

\section{Bibliografia}

Calabi, Francesca. História do pensamento judaico-helenistico. São Paulo: Loyola, 2013. . Fílon de Alexandria. São Paulo: Paulus, 2014.

Celam Os cristãos na universidade. Petrópolis: Vozes, 1968.

Concílio Vaticano II. Compêndio do Vaticano II. Petrópolis: Vozes, 1986.

. "Declaração Gravissimum educationis sobre a educação cristā". In Compêndio do Vaticano II, 581-586. Petrópolis: Vozes, 1986.

Congregación para la Educación Católica. "Educar para o diálogo intercultural na escola católica. Vivir juntos una civilización de amor". Vatican, http:// www.vatican.va/roman_curia/congregations/ccatheduc/documents/rc_con_ ccatheduc_doc_20131028_dialogo-interculturale_sp.html (acesso em 25 de Agosto de 2014).

De Aquino, Tomás. Suma teológica. Vol. IV. São Pulo: Loyola, 2005.

De Ridder-Symoens, Hilde. História da universidade europeia. Vol. I. Lisboa: Imprensa Nacional-Casa da Moeda, 1992.

Foulquié, Paul (org.). A Igreja e a educação. Rio de Janeiro: Agir, 1957.

Francisco. Exortação Evangelii gaudium. São Paulo: Paulinas, 2013. . Encíclica Laudato si. São Paulo: Paulus, 2015. 
Grant, Edward. História da filosofia natural: do mundo antigo ao século XIX. São Paulo: Madras, 2009.

Jaeger, Werner. Cristianismo primitivo y paideia griega. Mexico: Fondo de Cultura Económica, 1999.

Japiassu, Hilton. Ciência e destino humano. Rio de Janeiro: Imago, 2005.

João Paulo II. Constituição apostólica Ex corde ecclesiae. São Paulo: Paulinas, 2000. . Fides et ratio. São Paulo: Loyola, 1998.

Leão XIII. “Encíclica Aeterni patris (1879)”. In Documentos de Leão XXIII. São Paulo: Paulus, 2005.

. "Encíclica Rerum novarum (1891)". In Documentos de Leão XXIII. São Paulo: Paulus, 2005.

Leers, Bernardino. Moral cristã e autoridade do magistério eclesiástico. Conflito-diálogo. Aparecida: Santuário, 1991.

Nemo, Philippe. O que é o Ocidente? Sáo Paulo: Martins, 2005.

0’Malley, John W. O que aconteceu no Vaticano II. São Paulo: Loyola, 2014.

Pio XI. Encíclica Divini illius magistri. Rio de Janeiro: Agir, 1957.

- "Deus scientiarum dominus. Consttución apostólica sobre las universidades y las facultades de estudios eclesiásticos". Mercaba, http://www.mercaba.org/ PIO\%20XI/deus_scientiarum_dominus.htm (acesso em 25 de agosto de 2014).

Stein, Gesuída B. A educação nos documentos da Igreja Católica Apostólica Romana. Brasília: Universa Editora, 2001.

Tarnas, Richard. A epopeia do pensamento ocidental. Rio de Janeiro: Bertrand Brasil, 1999.

Theissen, Gerd. A religião dos primeiros cristäos: uma teoria do cristianismo primitivo. São Paulo: Paulinas, 2009.

Verger, Jacques. Cultura, ensino e sociedade no Ocidente nos séculos XII e XIII. Baruru: Edusc, 2001.

Vilanova, Evangelista. Historia de la teología cristiana. Vol. I. Barcelona: Herder, 1987. 